\title{
Saturation transfer difference NMR spectroscopy for the elucidation of supramolecular protein-polymer interactions
}

\author{
You Dan Xuª, Rebecca Yong Laia ${ }^{a}$ Eliška Procházkováb and Martina Stenzel ${ }^{\star a}$ \\ ${ }^{a}$ Centre for Advanced Macromolecular Design, School of Chemistry, The University of New \\ South Wales, Sydney 2052, NSW, Australia \\ ${ }^{b}$ Institute of Organic Chemistry and Biochemistry, The Czech Academy of Sciences, Prague \\ 166 10, Czech Republic
}

$\underline{\text { m.stenzel@unsw.edu.au }}$

Supplementary Information 


\section{Table of Contents}

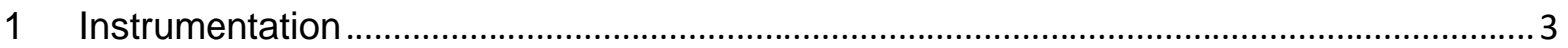

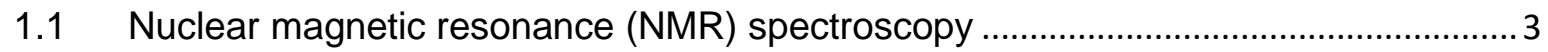

1.2 Electrospray ionization (ESI) mass spectrometry .................................................... 3

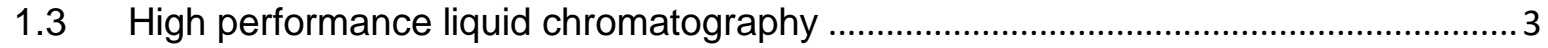

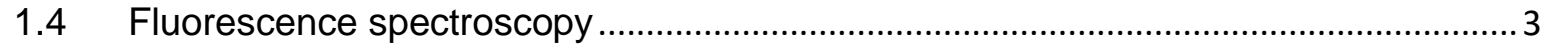

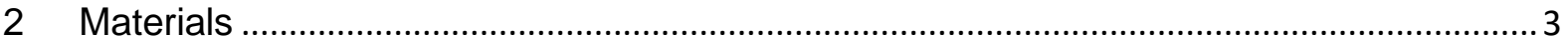

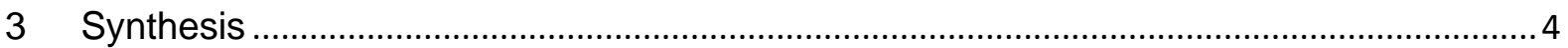

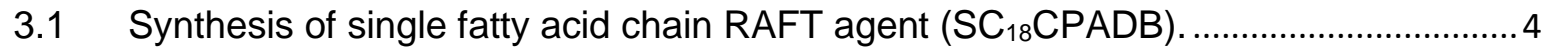

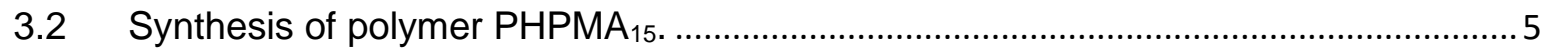

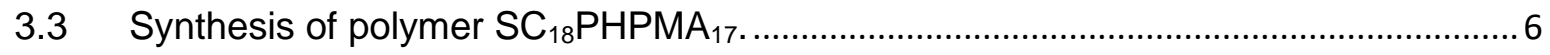

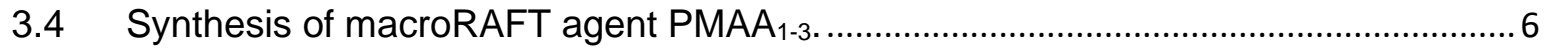

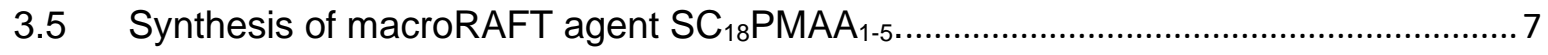

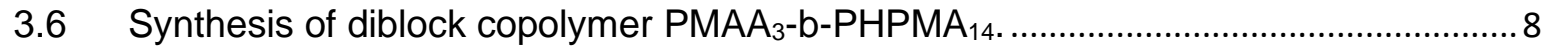

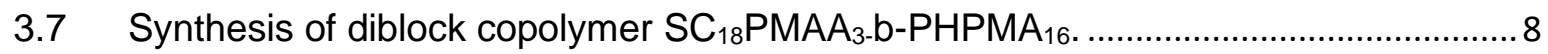

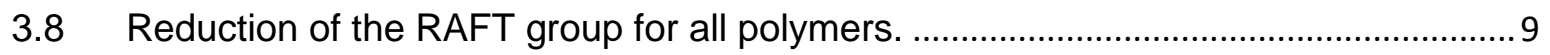

4 Saturation Transfer Difference NMR (STD-NMR) ............................................................. 9

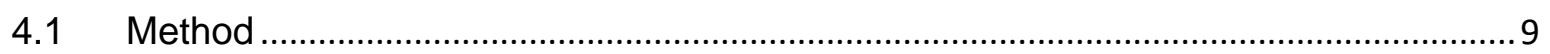

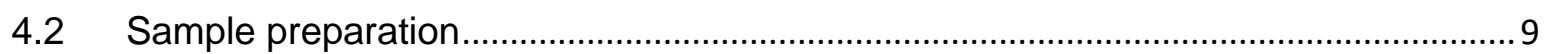

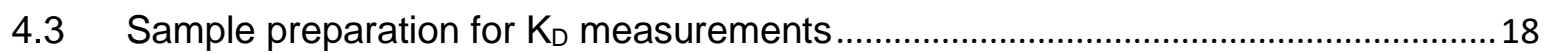

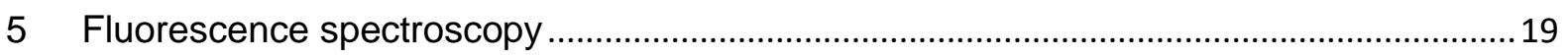

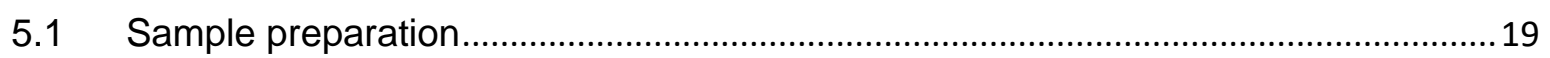

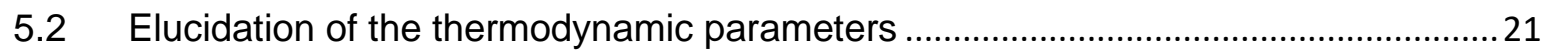

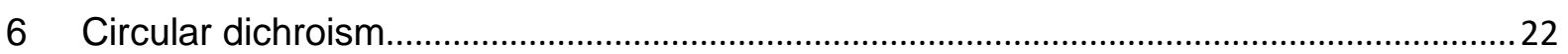

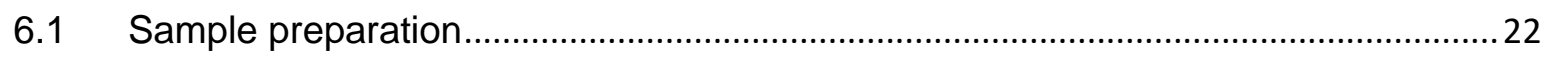

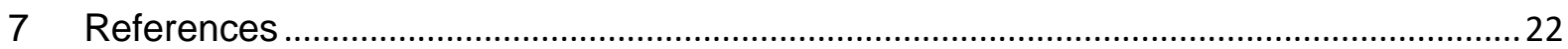




\section{Instrumentation}

1.1 Nuclear magnetic resonance (NMR) spectroscopy

NMR experiments for compound characterization such as ${ }^{1} \mathrm{H}$ or ${ }^{13} \mathrm{C}$, standard Bruker pulse sequences) were acquired on a Bruker Avance III NMR spectrometer operating at $400 \mathrm{MHz}$ for $1 \mathrm{H}(14 \mathrm{~T})$. The samples were measured in deuterated chloroform, at room temperature and referenced to TMS $(\delta=0 \mathrm{ppm})$ using the residual solvent signal $\left({ }^{1} \mathrm{H} 7.27 \mathrm{ppm}\right.$ and ${ }^{13} \mathrm{C} 77.0$ ppm), then processed using Bruker Topspin V3 software.

Saturation transfer difference NMR spectra were recorded on a Bruker Avance III NMR spectrometer operating at $600 \mathrm{MHz}$ for ${ }^{1} \mathrm{H}(14 \mathrm{~T})$ fitted with a $5 \mathrm{~mm} \mathrm{HCN} \mathrm{TCl}$-cryo-probe.

1.2 Electrospray ionization (ESI) mass spectrometry ESI-MS measurements were conducted on a Thermo Scientific LCQ Fleet in negative mode with methanol as the eluent.

\subsection{High performance liquid chromatography (HPLC)}

Semi-preparative high performance liquid chromatography (HPLC) was undertaken on a Shimadzu Prominence UFLC HPLC system using a Grace ${ }^{\text {TM }}$ Vision C18 HL $5 \mu \mathrm{m} 150 \times 22$ $\mathrm{mm}$ preparative column with an injection volume of $1.5 \mathrm{~mL}$ and flow rate of $5 \mathrm{~mL} / \mathrm{min}$. Samples were prepared at a concentration of $5 \mathrm{mg} \mathrm{mL}^{-1}$ using a $1: 1$ ratio of the mobile phases and filtered through a $0.45 \mu \mathrm{m}$ filter. The mobile phase consisted of two eluents: A (water with $0.1 \%$ formic acid) and $B$ (acetonitrile with $0.1 \%$ formic acid). Separation was achieved using a gradient from $50 \%$ B to $100 \%$ B over the course of 30 minutes.

\subsection{Fluorescence spectroscopy}

The fluorescence spectra of polymers with BSA and its conjugates were measured with Cary Eclipse fluorescence spectrophotometer equipped with a Cary Single Cell Peltier Accessory with recirculating water for temperature control. The samples were injected into a $1 \mathrm{~cm}$ path length quartz cuvette and their subsequent spectra were measured from $300-500 \mathrm{~nm}$ where $\lambda_{\text {ex }}=290 \mathrm{~nm}$ and emission/excitation slits were set to $10 \mathrm{~mm}$. All samples were measured at 25,30 and $35^{\circ} \mathrm{C}$.

\section{Materials}

4-cyanopentanoic acid dithiobenzoate (CPADB) was synthesized based on a protocol by Mitsukami et al. ${ }^{1}$ Azobisisobutyronitrile (AIBN) was recrystallised from methanol. N-(2hydroxypropyl)methacrylamide (HPMA) was synthesized according to a protocol by Fairbanks 
et $a .^{2} \quad N$-hydroxysuccinimide (NHS, Sigma-Aldrich), $N$-(3-dimethylaminopropyl)- $N$ ethylcarbodiimide hydrochloride (EDC.HCl, Merck), chloroform (Chem-Supply), ethyl acetate (EtOAc, Chem-Supply), hexane (Chem-Supply), stearamine (Fluka), magnesium sulfate $\left(\mathrm{MgSO}_{4}\right.$, Chem-Supply), deuterated chloroform $\left(\mathrm{CDCl}_{3}\right.$, Novachem), 1,4-dioxane (SigmaAldrich), methanol (MeOH, Chem-Supply), diethyl ether (Chem-Supply), deuterated dimethyl sulfoxide (DMSO- $d_{6}$, Novachem), methacrylic acid (MAA, Sigma-Aldrich), acetonitrile (ChemSupply), formic acid (Chem-Supply), toluene (Chem-Supply), sodium borohydride (SigmaAldrich), dimethylformamide (DMF, Chem-Supply), tris(2-carboxyethyl)phosphine (TCEP, Sigma-Aldrich), deuterium oxide (Novachem).

\section{Synthesis}

3.1 Synthesis of single fatty acid chain RAFT agent ( $\left.\mathrm{SC}_{18} \mathrm{CPADB}\right)$.

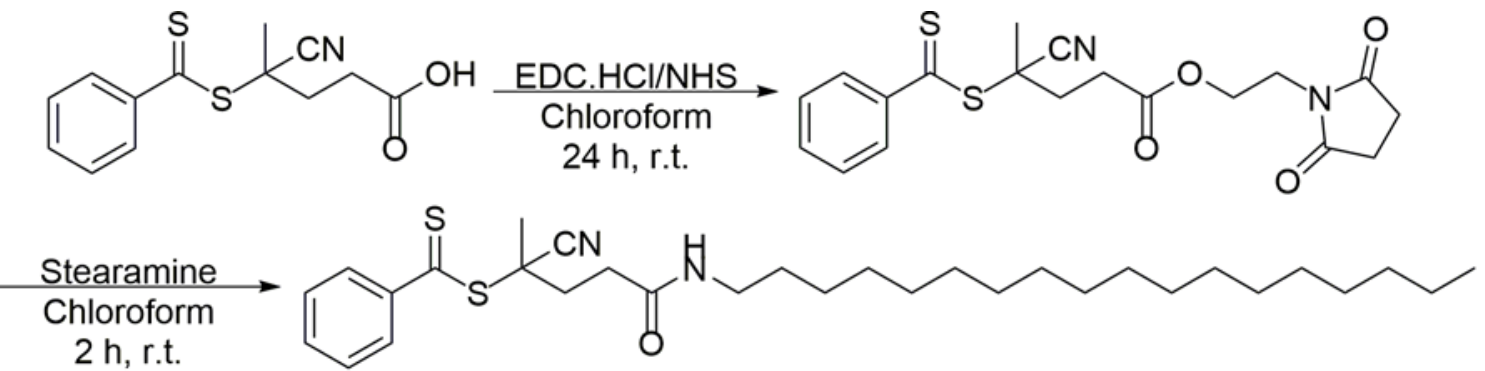

4-cyanopentanoic acid dithiobenzoate (CPADB, $\left.1.00 \mathrm{~g}, 3.58 \times 10^{-3} \mathrm{~mol}\right)$ and NHS (0.412 g, $\left.3.58 \times 10^{-3} \mathrm{~mol}\right)$ were dissolved chloroform $(10 \mathrm{~mL})$ under stirring. $\mathrm{N}$-(3-Dimethylaminopropyl)$N$-ethylcarbodiimide hydrochloride (EDC. $\left.\mathrm{HCl}, 0.686 \mathrm{~g}, 3.58 \times 10^{-3} \mathrm{~mol}\right)$ in chloroform $(5 \mathrm{~mL})$ was added dropwise to the stirring solution. The reaction was monitored by TLC with a 1:1 EtOAc/Hexane solvent system. Upon complete conversion to the NHS-conjugated derivative, stearamine $\left(0.965 \mathrm{~g}, 3.58 \times 10^{-3} \mathrm{~mol}\right)$ in chloroform $(10 \mathrm{~mL})$ was added dropwise to the solution. Reaction was monitored by TLC with a 1:1 EtOAc/Hexane solvent system. The crude was washed once with acidified water $(40 \mathrm{~mL})$ and twice with MilliQ water $(40 \mathrm{~mL} \times 2)$ before drying with anhydrous $\mathrm{MgSO}_{4}$. The solvent was removed in vacuo before purification by column chromatography with a 2:1 EtOAc/Hexane solvent system. Solvent was removed in vacuo to afford a bright pink solid, $\mathrm{SC}_{18} \mathrm{CPADB}$ (Yield = $67 \%$ ). ${ }^{1} \mathrm{H}$ NMR $\left(400 \mathrm{MHz}, \mathrm{CDCl}_{3}, 298 \mathrm{~K}\right.$, ppm, ठ): 7.91 (d, 2H, -Ar), 7.56 (t, 1H, -Ar), 7.39 (t, 2H, -Ar), 5.54 (s, 1H, -NH), $3.25\left(\mathrm{~m}, 2 \mathrm{H},-\mathrm{NHCH}_{2}\right)$, 2.68-2.38 (m, 4H, $\left.2 \times-\mathrm{CH}_{2}\right), 1.94\left(\mathrm{~s}, 3 \mathrm{H},-\mathrm{CH}_{3}\right), 1.35-1.20\left(\mathrm{~s}, 32 \mathrm{H},-\mathrm{CH}_{2}\right), 0.88\left(\mathrm{t}, 3 \mathrm{H},-\mathrm{CH}_{3}\right)$. ${ }^{13} \mathrm{C}$ NMR $\left(75 \mathrm{MHz}, \mathrm{CDCl}_{3}, 298 \mathrm{~K}, \mathrm{ppm}, \delta\right): 170.4,144.8,133.2,128.8,126.9,118.9,46.3$, $40.0,34.4,32.2,29.8,27.1,24.4,22.9,14.3$. 


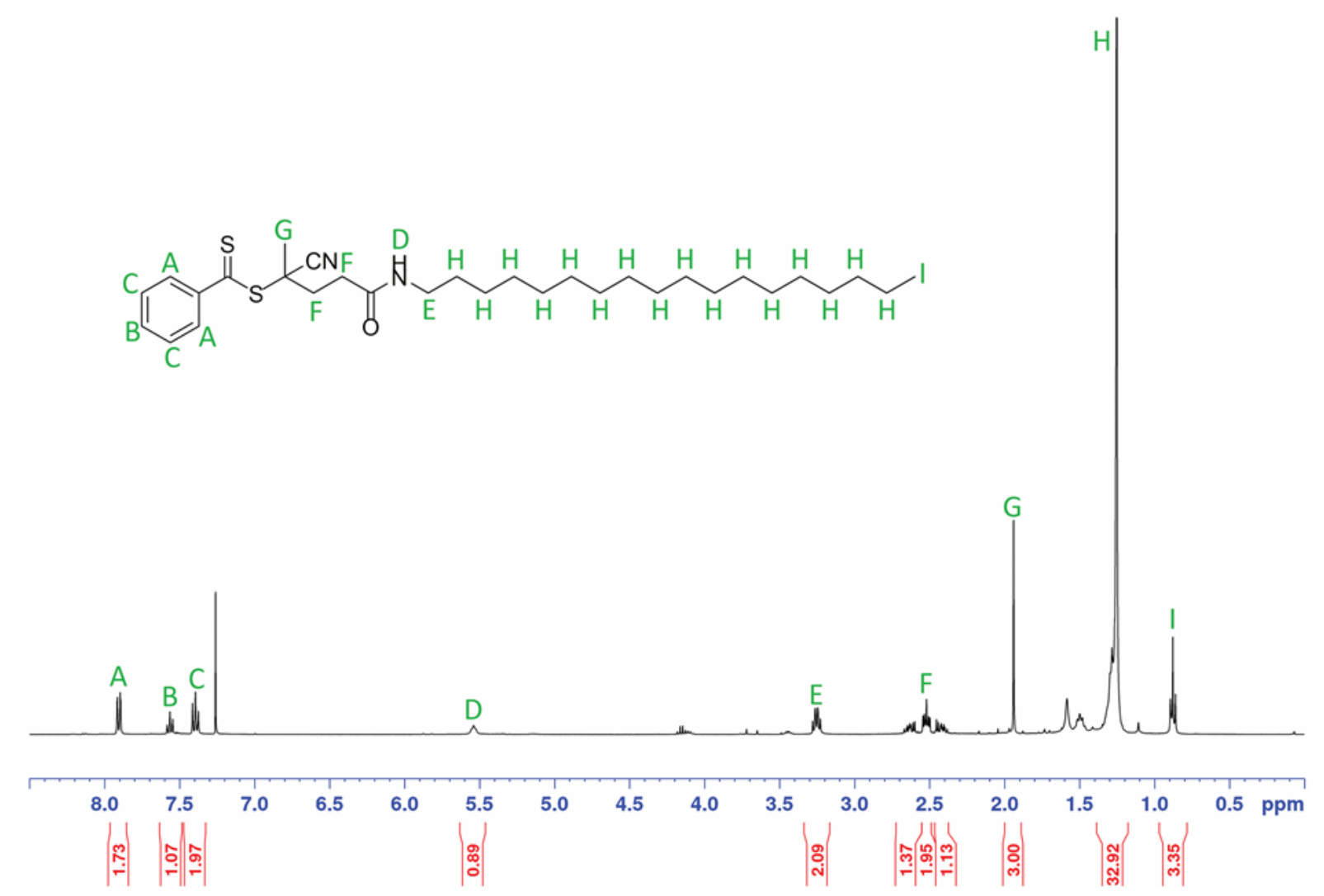

Figure S1. ${ }^{1} \mathrm{H}$ NMR (300 MHz, $\mathrm{CDCl}_{3}$ ) spectrum of $\mathrm{SC}_{18} \mathrm{CPADB}$ RAFT agent.

3.2 Synthesis of polymer PHPMA 15.

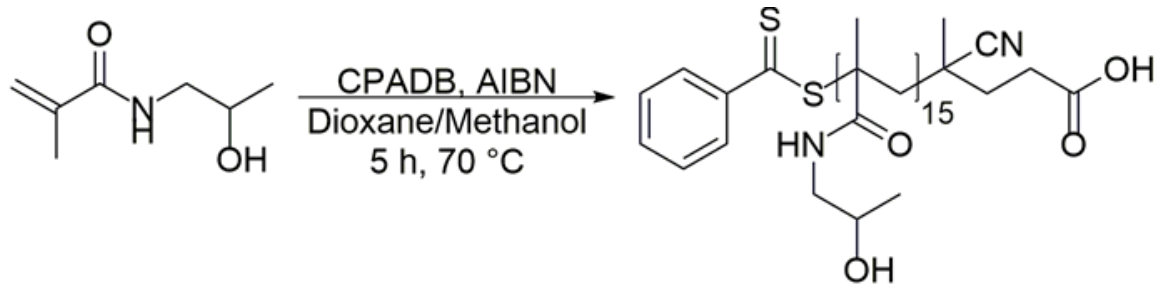

HPMA $\left(0.738 \mathrm{~g}, 5.15 \times 10^{-3} \mathrm{~mol}\right)$, CPADB $\left(0.030 \mathrm{~g}, 1.07 \times 10^{-4} \mathrm{~mol}\right)$ and AIBN $\left(5.81 \times 10^{-3} \mathrm{~g}\right.$, $\left.3.54 \times 10^{-5} \mathrm{~mol}\right)$ were dissolved in $2: 1$ dioxane/methanol $(4.12 \mathrm{~mL})$, affording a monomer concentration of $1.25 \mathrm{mmol} / \mathrm{mL}$. The [M]:[RAFT]:[l] ratio was $48: 1: 0.33$. The solution was purged with nitrogen for $10 \mathrm{~min}$ at $0^{\circ} \mathrm{C}$ before polymerisation proceeded at $70{ }^{\circ} \mathrm{C}$ for $5 \mathrm{~h}$ under stirring. The reaction was terminated by the introduction of air and cooling the solution to $0{ }^{\circ} \mathrm{C}$. Product was purified by precipitating thrice in diethyl ether $(40 \mathrm{~mL} \times 3)$ and confirmation of the polymer chain was obtained via ${ }^{1} \mathrm{H}$ NMR. ${ }^{1} \mathrm{H}$ NMR $\left(400 \mathrm{MHz}\right.$, DMSO- $\left.d_{6}, 298 \mathrm{~K}, \mathrm{ppm}, \delta\right): 7.80$ (t, 2H, -Ar), 7.60 (t, 1H, -Ar), 7.45 (t, 2H, -Ar), 7.18 (s, 15H, -NH), 4.72 (s, 15H, -OH), 3.67 (s, $15 \mathrm{H},-\mathrm{CH}), 2.93\left(\mathrm{~s}, 30 \mathrm{H},-\mathrm{CH}_{2}\right), 1.92-1.44\left(\mathrm{~m}, 30 \mathrm{H},-\mathrm{CH}_{2}\right), 1.24-0.58\left(\mathrm{t}, 90 \mathrm{H},-\mathrm{CH}_{3}\right)$. 
3.3 Synthesis of polymer $\mathrm{SC}_{18} \mathrm{PHPMA}_{17}$.

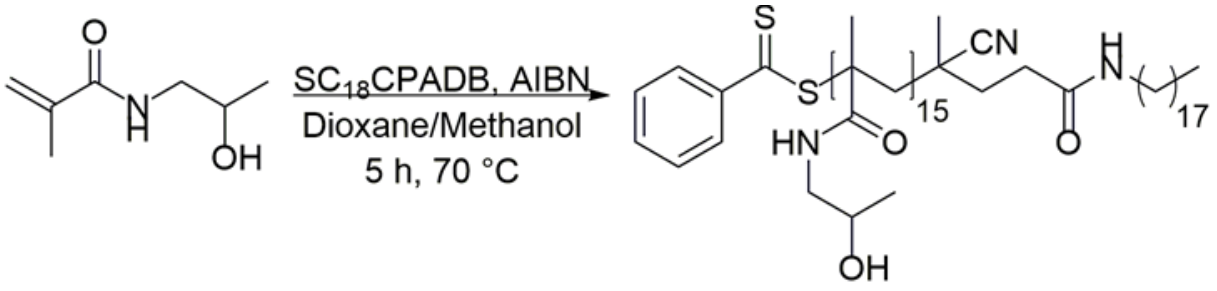

HPMA $\left(0.647 \mathrm{~g}, 4.52 \times 10^{-3} \mathrm{~mol}\right), \mathrm{SC}_{18}$ CPADB $\left(0.050 \mathrm{~g}, 9.42 \times 10^{-5} \mathrm{~mol}\right)$ and AIBN $\left(5.10 \times 10^{-}\right.$ $\left.{ }^{3} \mathrm{~g}, 3.11 \times 10^{-5} \mathrm{~mol}\right)$ were dissolved in 1:1 dioxane/methanol $(3.62 \mathrm{~mL})$, affording a monomer concentration of $1.25 \mathrm{mmol} / \mathrm{mL}$. The [M]:[RAFT]:[l] ratio was 48:1:0.33. The solution was purged with nitrogen for $10 \mathrm{~min}$ at ambient temperature before polymerisation proceeded at $70{ }^{\circ} \mathrm{C}$ for $5 \mathrm{~h}$ under stirring. The reaction was terminated by the introduction of air and cooling the solution to $0{ }^{\circ} \mathrm{C}$. Product was purified by precipitating thrice in diethyl ether $(40 \mathrm{~mL} \times 3)$ and confirmation of the polymer chain was obtained via ${ }^{1} \mathrm{H}$ NMR. ${ }^{1} \mathrm{H}$ NMR (400 MHz, DMSO$d_{6}, 298 \mathrm{~K}, \mathrm{ppm}, \delta$ ): 7.81 (t, 2H, -Ar), 7.60 (t, 1H, -Ar), 7.45 (t, 2H, -Ar), 7.17 (s, 17H, -NH), 4.70 $(\mathrm{s}, 17 \mathrm{H},-\mathrm{OH}), 3.67(\mathrm{~s}, 17 \mathrm{H},-\mathrm{CH}), 2.91\left(\mathrm{~s}, 35 \mathrm{H},-\mathrm{CH}_{2}\right), 2.07-1.46\left(\mathrm{~m}, 35 \mathrm{H},-\mathrm{CH}_{2}\right), 1.24(\mathrm{t}, 32 \mathrm{H}$, $\left.-\mathrm{CH}_{2}\right)$ 1.09-0.74 (m, 106, $\left.\mathrm{CH}_{3}\right)$.

3.4 Synthesis of macroRAFT agent $\mathrm{PMAA}_{1-3}$.

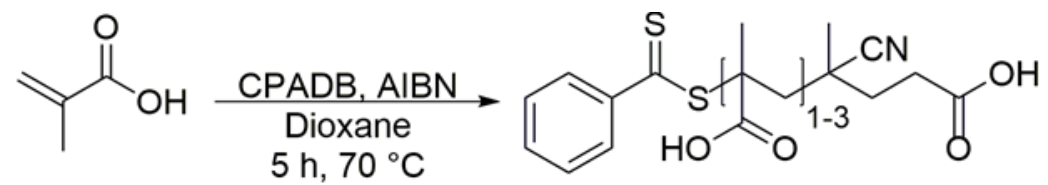

MAA $\left(0.308 \mathrm{~g}, 3.58 \times 10^{-3} \mathrm{~mol}\right)$, CPADB $\left(0.100 \mathrm{~g}, 3.58 \times 10^{-4} \mathrm{~mol}\right)$ and AIBN $\left(5.88 \times 10^{-3} \mathrm{~g}\right.$, $\left.3.58 \times 10^{-5} \mathrm{~mol}\right)$ were dissolved in dioxane $(3.58 \mathrm{~mL})$, affording a monomer concentration of 1 $\mathrm{mmol} / \mathrm{mL}$. The [M]:[RAFT]:[I] ratio was 10:1:0.1. The solution was purged with nitrogen for 10 $\min$ at $0{ }^{\circ} \mathrm{C}$ before polymerisation proceeded at $70{ }^{\circ} \mathrm{C}$ for $5 \mathrm{~h}$ under stirring. The reaction was terminated by the introduction of air and cooling the solution to $0{ }^{\circ} \mathrm{C}$. Dioxane was removed under vacuum and a small fraction of the crude product was dissolved in methanol for ESIMS analysis. The purification of PMAA polymers between 1-5 units long was achieved via HPLC with a $1: 1$ acetonitrile/MilliQ water solvent system with $0.1 \%$ formic acid. Confirmation of polymers between 1-3 units long was attained by ESI-MS ( $\mathrm{m} / \mathrm{z}$ calcd. $[\mathrm{M}-\mathrm{H}]^{-}=364.44,450.50$, 536.56 ; found $=364.00,450.00,536.08$ for 1,2 and 3 units of MAA respectively). 
3.5 Synthesis of macroRAFT agent $\mathrm{SC}_{18} \mathrm{PMAA}_{1-5}$.

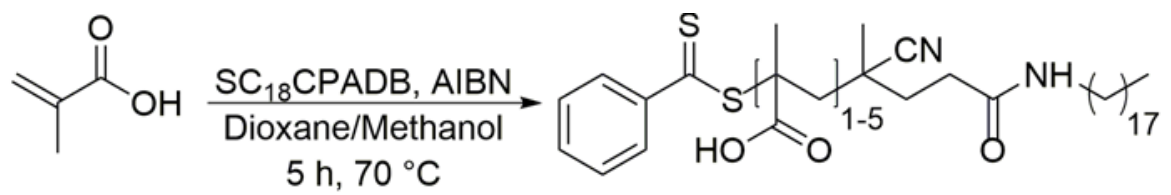

MAA $\left(0.162 \mathrm{~g}, 1.88 \times 10^{-3} \mathrm{~mol}\right)$, CPADB $\left(0.100 \mathrm{~g}, 1.88 \times 10^{-4} \mathrm{~mol}\right)$ and AIBN $\left(3.09 \times 10^{-3} \mathrm{~g}\right.$, $\left.1.88 \times 10^{-5} \mathrm{~mol}\right)$ were dissolved in $1: 1$ dioxane/toluene $(1.88 \mathrm{~mL})$, affording a monomer concentration of $1 \mathrm{mmol} / \mathrm{mL}$. The [M]:[RAFT]:[l] ratio was 10:1:0.1. The solution was purged with nitrogen for $10 \mathrm{~min}$ at ambient temperature before polymerisation proceeded at $70{ }^{\circ} \mathrm{C}$ for $5 \mathrm{~h}$ under stirring. The reaction was terminated by the introduction of air and cooling the solution to $0{ }^{\circ} \mathrm{C}$. Product was purified by precipitating thrice in hexane $(40 \mathrm{~mL} \times 3)$ and confirmation of polymers between $1-5$ units long was attained by ESI-MS ( $\mathrm{m} / \mathrm{z}$ calcd. $[\mathrm{M}-\mathrm{H}]^{-}$ $=615.93,701.99,788.05,874.11,960.17$; found $=615.25,701.33,787.33,873.33$, 959.33 for $1,2,3,4$ and 5 units of MAA respectively).

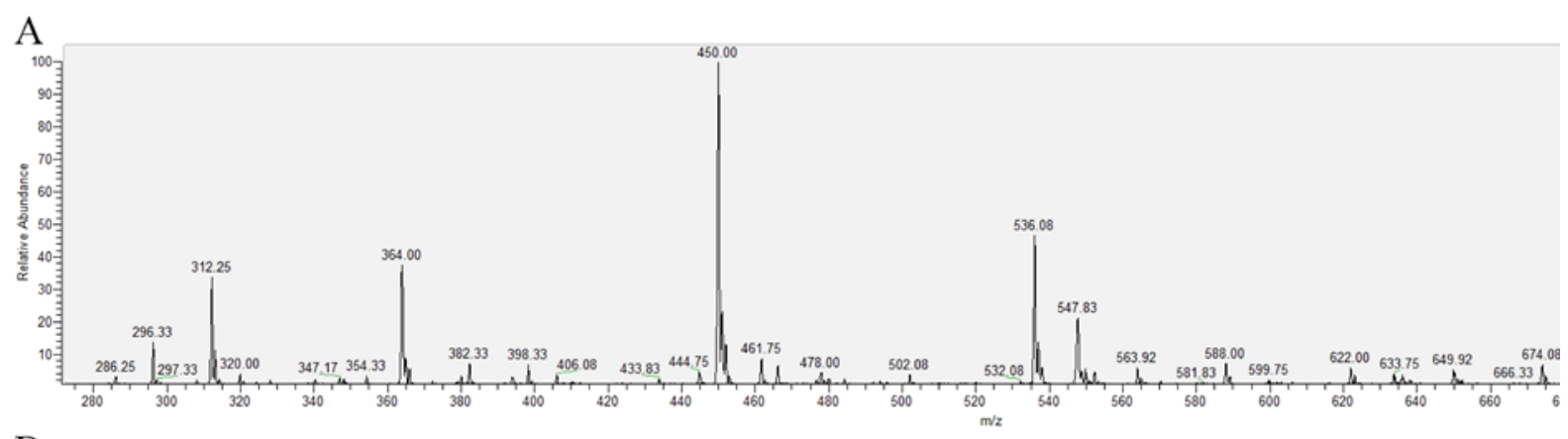

$\mathrm{B}$

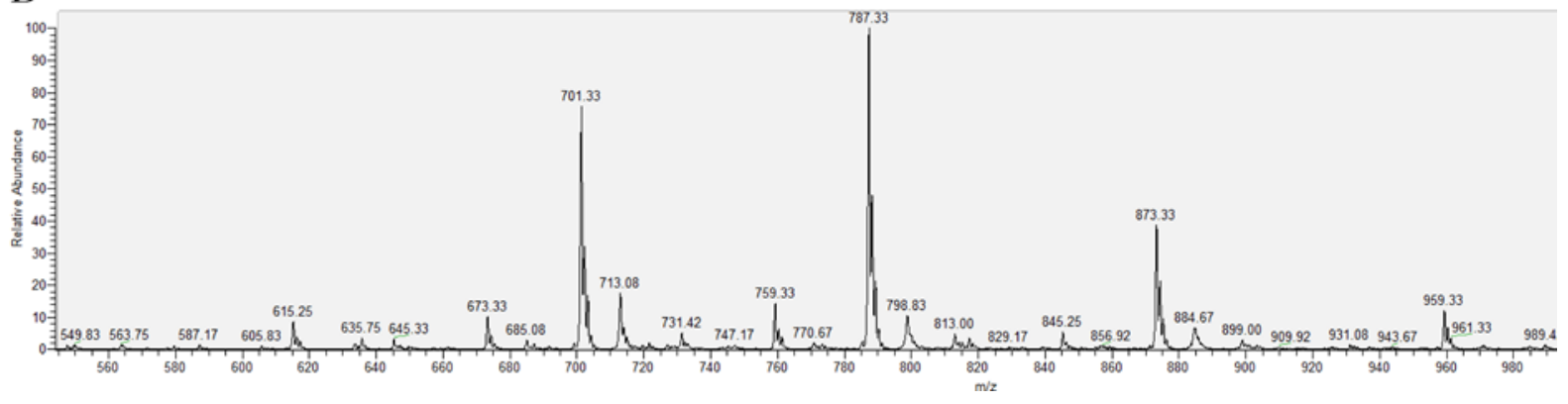

Figure S2. ESI-MS spectra of $A$ ) $\mathrm{PMAA}_{1-3}$ and $\left.B\right) \mathrm{SC}_{18} \mathrm{PMAA}_{1-5}$ obtained in negative mode. 
3.6 Synthesis of diblock copolymer PMAA3-b-PHPMA 14 .<smiles>C=C(C)C(=O)NCC(C)O</smiles>

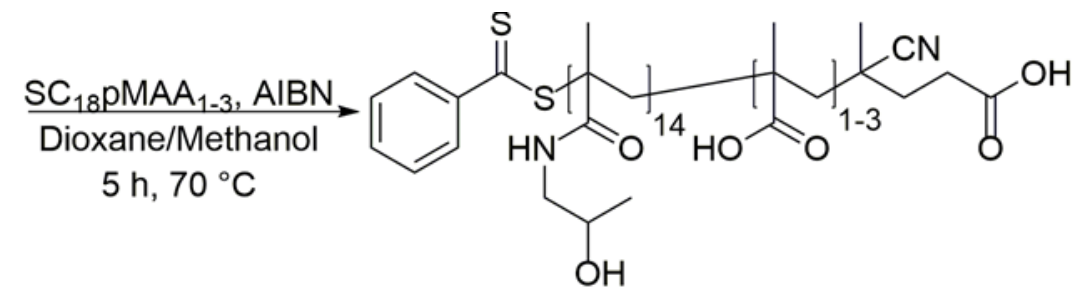

HPMA (0.384 g, $\left.2.68 \times 10^{-3} \mathrm{~mol}\right)$, PMAA $1-5$ macroRAFT $\left(0.030 \mathrm{~g}, 5.58 \times 10^{-4} \mathrm{~mol}\right)$ and AIBN $\left(3.02 \times 10^{-3} \mathrm{~g}, 1.84 \times 10^{-5} \mathrm{~mol}\right)$ were dissolved in $1: 1$ dioxane/methanol $(2.14 \mathrm{~mL})$, affording a monomer concentration of $1.25 \mathrm{mmol} / \mathrm{mL}$. The [M]:[RAFT]:[l] ratio was 48:1:0.33. The solution was purged with nitrogen for $10 \mathrm{~min}$ at $0{ }^{\circ} \mathrm{C}$ before polymerisation proceeded at $70{ }^{\circ} \mathrm{C}$ for $5 \mathrm{~h}$ under stirring. The reaction was terminated by the introduction of air and cooling the solution to $0{ }^{\circ} \mathrm{C}$. Product was purified by precipitating thrice in diethyl ether $(40 \mathrm{~mL} \times 3$ ) and confirmation of HPMA block was obtained via ${ }^{1} \mathrm{H}$ NMR. ${ }^{1} \mathrm{H}$ NMR $\left(400 \mathrm{MHz}\right.$, DMSO- $d_{6}, 298 \mathrm{~K}$, ppm, ठ): 12.30 (s, 1H, -COOH), 7.81 (t, 2H, -Ar), 7.61 (t, 1H, -Ar), 7.45 (t, 2H, -Ar), 7.17 (m, $14 \mathrm{H},-\mathrm{NH}), 4.69(\mathrm{~s}, 14 \mathrm{H},-\mathrm{OH}), 3.67(\mathrm{~s}, 14 \mathrm{H},-\mathrm{CH}), 2.92\left(\mathrm{~s}, 28 \mathrm{H},-\mathrm{CH}_{2}\right), 1.99-1.43(\mathrm{~m}, 32 \mathrm{H},-$ $\left.\mathrm{CH}_{2}\right), 1.11-0.62\left(\mathrm{~m}, 96 \mathrm{H},-\mathrm{CH}_{3}\right)$.

3.7 Synthesis of diblock copolymer $\mathrm{SC}_{18} \mathrm{PMAA}_{3}-\mathrm{b}-\mathrm{PHPMA} 16$.<smiles>C=C(C)C(=O)NCC(C)O</smiles>

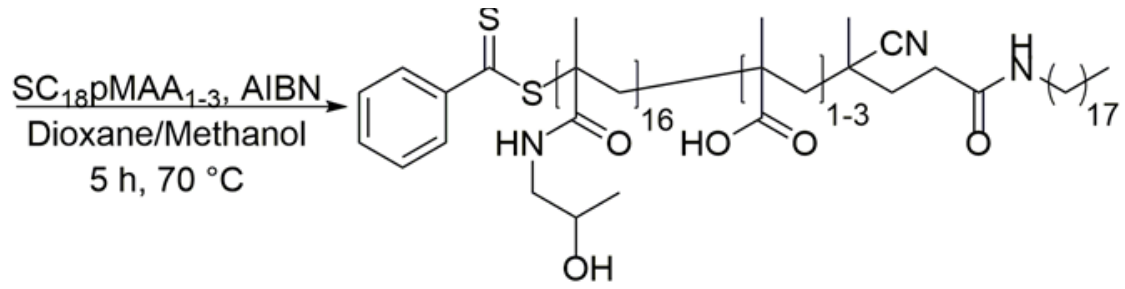

HPMA $\left(0.054 \mathrm{~g}, 3.80 \times 10^{-4} \mathrm{~mol}\right), \mathrm{SC}_{18} \mathrm{PMAA}_{3}$ macroRAFT $\left(0.030 \mathrm{~g}, 3.80 \times 10^{-5} \mathrm{~mol}\right)$ and AIBN $\left(2.06 \times 10^{-3} \mathrm{~g}, 1.25 \times 10^{-5} \mathrm{~mol}\right)$ were dissolved in $1: 1$ dioxane/methanol $(0.304 \mathrm{~mL})$, affording a monomer concentration of $1.25 \mathrm{mmol} / \mathrm{mL}$. The [M]:[RAFT]:[l] ratio was 10:1:0.33. The solution was purged with nitrogen for $10 \mathrm{~min}$ at $0{ }^{\circ} \mathrm{C}$ before polymerisation proceeded at $70{ }^{\circ} \mathrm{C}$ for $5 \mathrm{~h}$ under stirring. The reaction was terminated by the introduction of air and cooling the solution to $0{ }^{\circ} \mathrm{C}$. Product was purified by precipitating thrice in diethyl ether ( $40 \mathrm{~mL} \times 3$ ) and confirmation of HPMA block was obtained via ${ }^{1} \mathrm{H}$ NMR. ${ }^{1} \mathrm{H}$ NMR $\left(400 \mathrm{MHz}, \mathrm{CDCl}_{3}, 298 \mathrm{~K}\right.$, ppm, б): 7.81 (t, 2H, -Ar), 7.61 (t, 1H, -Ar), 7.45 (t, 2H, -Ar), $7.18(\mathrm{~s}, 16 \mathrm{H},-\mathrm{NH}), 4.70(\mathrm{~s}, 16 \mathrm{H},-\mathrm{OH})$, $3.67(\mathrm{~s}, 16 \mathrm{H},-\mathrm{CH}), 2.91(\mathrm{~s}, 32 \mathrm{H}), 2.07-1.46\left(\mathrm{~m}, 36 \mathrm{H},-\mathrm{CH}_{3}\right), 1.24\left(\mathrm{~s}, 32 \mathrm{H},-\mathrm{CH}_{2}\right), 1.11-0.58(\mathrm{t}$, $\left.114 \mathrm{H},-\mathrm{CH}_{3}\right)$. 
3.8 Reduction of the RAFT group for all polymers.

The removal of the phenyl moiety from the RAFT agent was undertaken post-polymerisation, closely following a method reported by McCormick and coworkers. ${ }^{3}$ Briefly, polymer was dissolved in $15 \mathrm{~mL}$ of MilliQ water under stirring. $1 \mathrm{M}$ sodium borohydride $(15 \mathrm{~mL})$ was added to the stirring solution and reaction proceeded for $2 \mathrm{~h}$. The resulting solution was dialysed against MilliQ water for two days before lyophilisation, obtaining a white fluffy solid. The polymer was redissolved in DMF $(5 \mathrm{~mL})$, followed by the addition of tris(2carboxyethyl)phosphine (TCEP) in DMF (10 mL) to achieve a molar TCEP:polymer ratio of 120:1. The second reduction step proceeded for $24 \mathrm{~h}$ before dialysis against MilliQ water for two days before lyophilisation.

\section{Saturation Transfer Difference NMR (STD-NMR)}

\subsection{Method}

Saturation transfer difference (STD) NMR studies were conducted in a DMSO- $d_{6} / \mathrm{D}_{2} \mathrm{O}(1: 3)$ cosolvent on Bruker Avance III $600 \mathrm{MHz}$ Cryo NMR spectrometer at sample temperature of 298K. The STD experiments were conducted by using a chain of Gauss-shaped pulses, according to the pulse program stddiffesgp3, with suppression of the residual HDO signal by presaturation using composite pulse and spoil gradient (zgcpgppr) scheme. The off-resonance spectrum was obtained by irradiating the sample at $-40 \mathrm{ppm}$, whilst the on-resonance spectrum of BSA was obtained by irradiating the sample at $0.65,2.60,4.30$ and $7.10 \mathrm{ppm}$. The spectra were acquired using the following parameters: spectral width $7.2 \mathrm{kHz}$, number of scans at 64, acquisition time $2 \mathrm{~s}$, saturation time $2 \mathrm{~s}$, and spin-lock $25 \mathrm{~ms}$, and processed using Bruker's Topspin V3.5.

\subsection{Sample preparation}

Polymer solutions were prepared in $\mathrm{PBS} \mathrm{D}_{2} \mathrm{O}(\mathrm{pH} \mathrm{7.4,75} \mathrm{mM})$ in NMR tubes. Additional PBS $\mathrm{D}_{2} \mathrm{O}$ was added to the tube to adjust the total volume to $370 \mu \mathrm{L}$ so that the final polymer concentration was $2 \mathrm{mM}$. DMSO- $d_{6}(150 \mu \mathrm{L})$ was then added to minimise any aggregation due to polymer amphiphilicity. The solution in the tube was thoroughly mixed before polymer NMR spectra of the polymer were recorded. Finally, BSA $(0.02 \mathrm{M})$ in PBS $\mathrm{D}_{2} \mathrm{O}(80 \mu \mathrm{L})$ was added to the polymer solution and thoroughly mixed before performing the experiment. The molar ratio of polymer:BSA was kept constant at $100: 1$ and the solvent system was $25 \%$ DMSO- $d_{6}$ in PBS $\mathrm{D}_{2} \mathrm{O}$. 
A

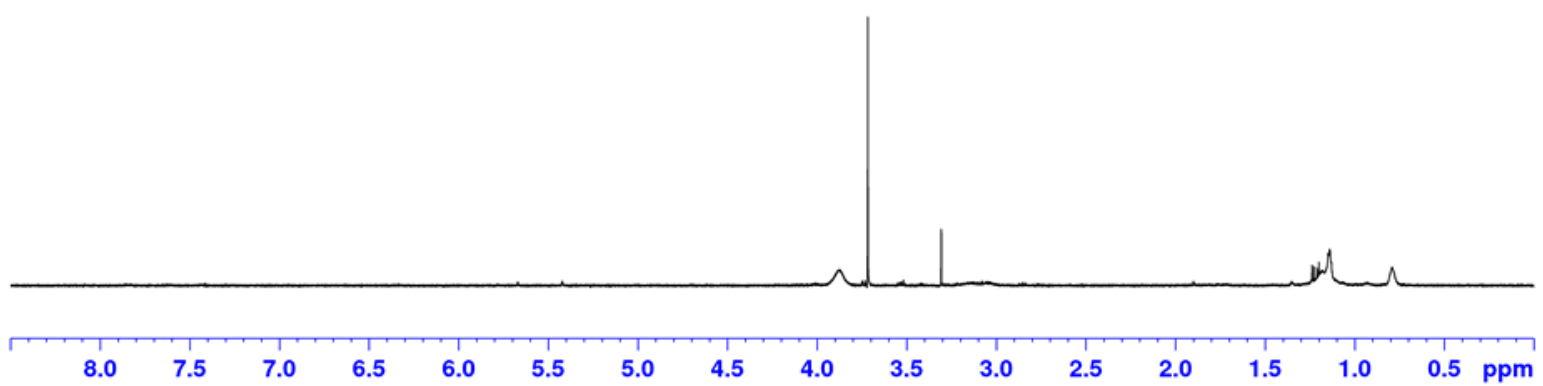

$\mathrm{B}$

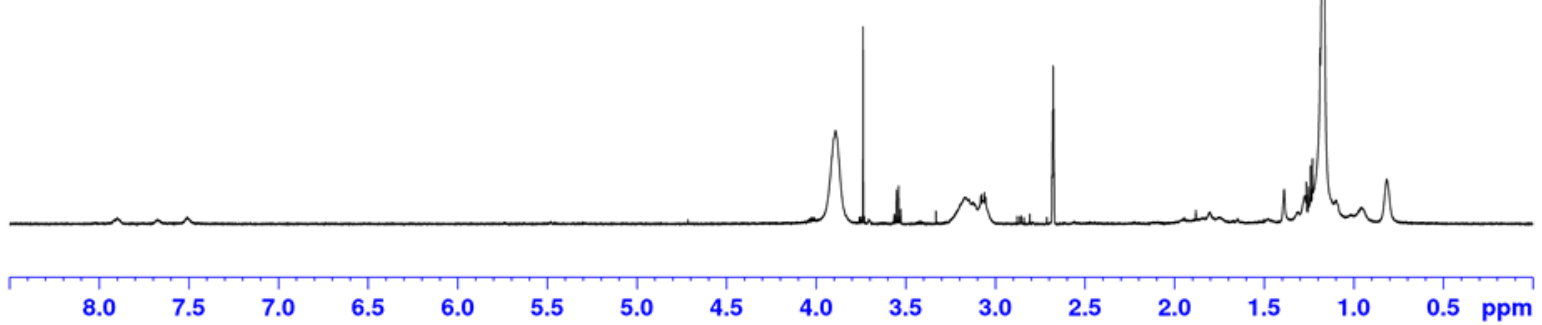

Figure S3. STD-NMR off-resonance spectra of polymer $3 a$ in A) $\mathrm{D}_{2} \mathrm{O}$ only and B) $\mathrm{D}_{2} \mathrm{O}$ and $25 \%$ DMSO$d_{6}(\mathrm{v} / \mathrm{v})$. 


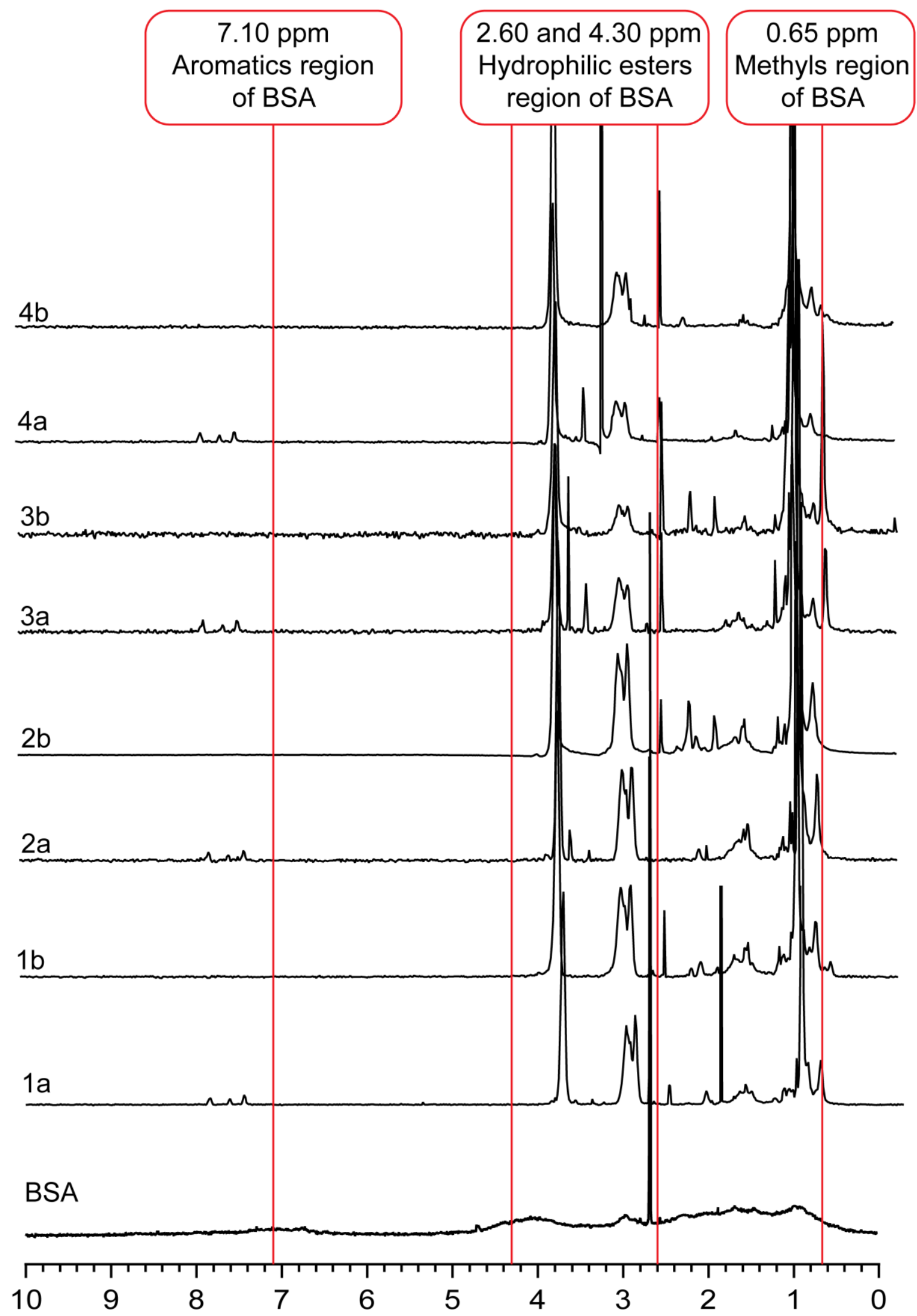

Figure S4. STD-NMR (600 MHz, 3:1 $\left.\mathrm{D}_{2} \mathrm{O} / \mathrm{DMSO}-d_{6}\right)$ spectra of the polymer library and BSA with the irradiation frequencies marked to show that generally no overlap with the polymer peaks occurs. The overlap that occurs at $0.65 \mathrm{ppm}$ generates a false positive and thus was not factored into the results. 

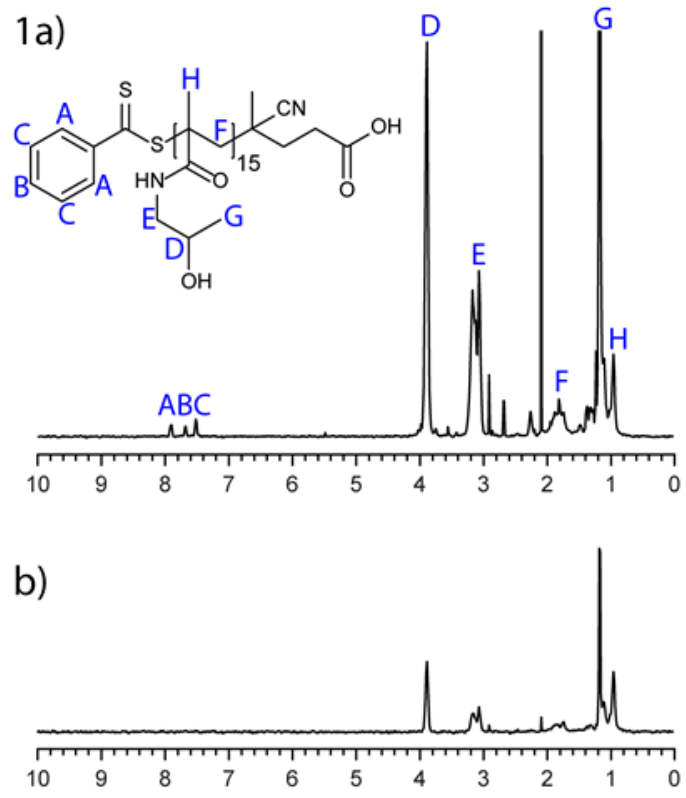

c)

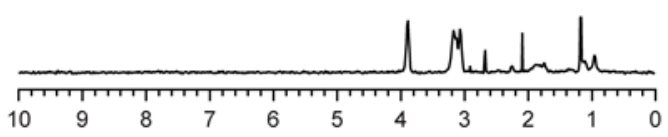

d)

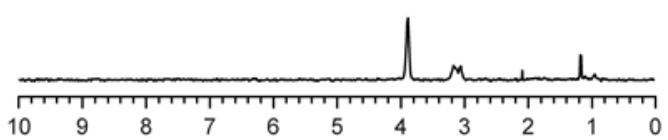

e)

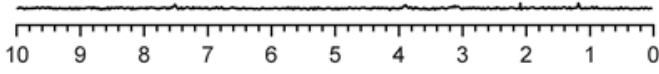

2a)

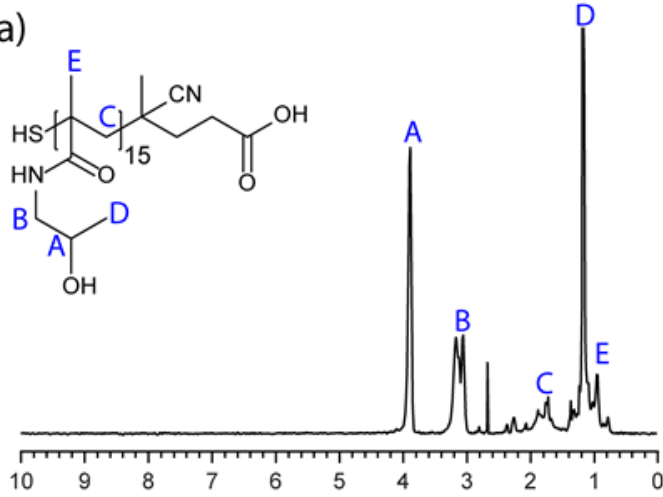

b)

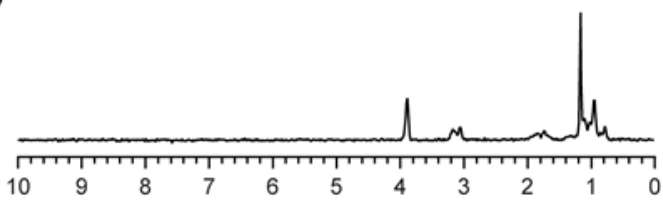

c)

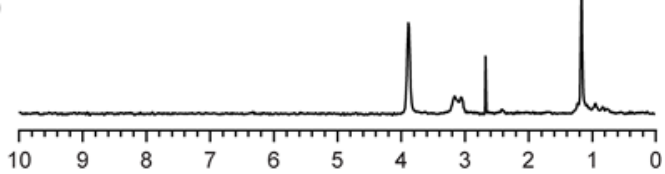

d)

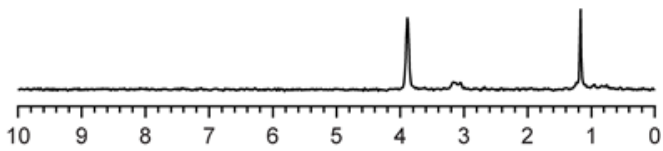

e)

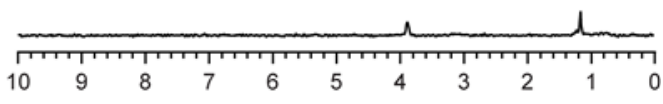

Figure S5. STD-NMR (600 MHz, 3:1 $\left.\mathrm{D}_{2} \mathrm{O} / \mathrm{DMSO}-d_{6}\right)$ spectra of 1) $1 \mathbf{a}$ and 2) 1b polymers with BSA. a) are the reference (off-resonance) spectra measured with selective irradiation at $-40 \mathrm{ppm}$. Spectra b) to e) are difference spectra obtained with selective irradiation at the frequencies: $0.65,2.60,4.30$ and 7.10 ppm, respectively.

Table S1. Amplification factors (AsтD) of 1a with BSA irradiated at multiple frequencies.

\begin{tabular}{|c|c|c|c|c|}
\hline \multirow{2}{*}{ BSA irradiation frequencies } & \multicolumn{3}{|c|}{ Amplification factors (AstD) } \\
\cline { 2 - 5 } & $\mathbf{0 . 6 5} \mathbf{~ p p m}$ & $\mathbf{2 . 6 0} \mathbf{~ p p m}$ & $\mathbf{4 . 3 0} \mathbf{~ p p m}$ & $\mathbf{7 . 1 0} \mathbf{~ p p m}$ \\
\hline Polymer peaks & Methyls & Hydrophilic esters & Aromatics \\
\hline Benzene (7.40-7.98 ppm) & $10.8 \%$ & $16.2 \%$ & $6.6 \%$ & $12.3 \%$ \\
\hline HPMA & $16.3 \%$ & $14.4 \%$ & $7.1 \%$ & $0.7 \%$ \\
\hline
\end{tabular}


Table S2. Amplification factors (AsTD) of $\mathbf{1 b}$ with BSA irradiated at multiple frequencies.

\begin{tabular}{|c|c|c|c|c|}
\hline \multirow{2}{*}{ BSA irradiation frequencies } & \multicolumn{4}{|c|}{ Amplification factors (AstD) } \\
\cline { 2 - 5 } & $\mathbf{0 . 6 5} \mathbf{~ p p m}$ & $\mathbf{2 . 6 0} \mathbf{~ p p m}$ & $\mathbf{4 . 3 0} \mathbf{~ p p m}$ & $\mathbf{7 . 1 0} \mathbf{~ p p m}$ \\
\hline Polymer peaks & Methyls & Hydrophilic esters & Aromatics \\
\hline Benzene (7.40-7.98 ppm) & - & - & - & - \\
\hline HPMA & $15.5 \%$ & $12.5 \%$ & $6.0 \%$ & $0.7 \%$ \\
\hline
\end{tabular}

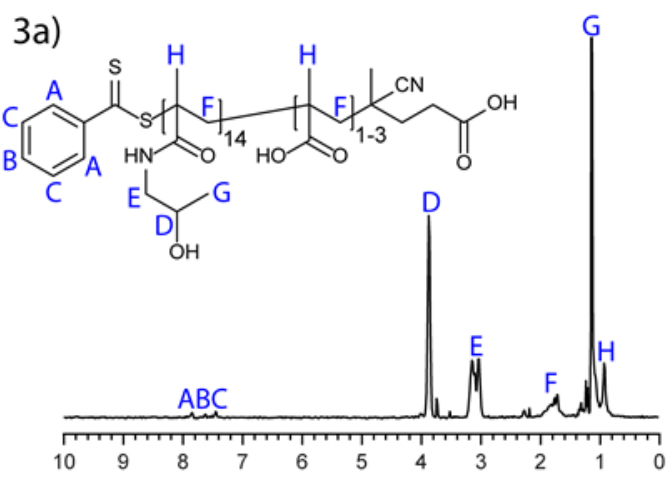

b)

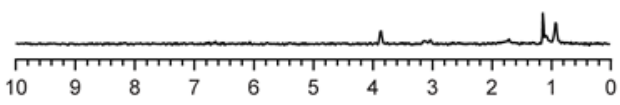

c)

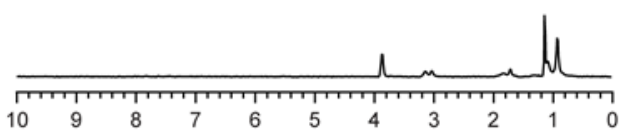

d)

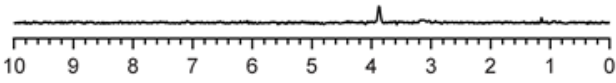

e)

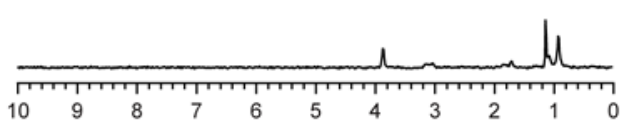

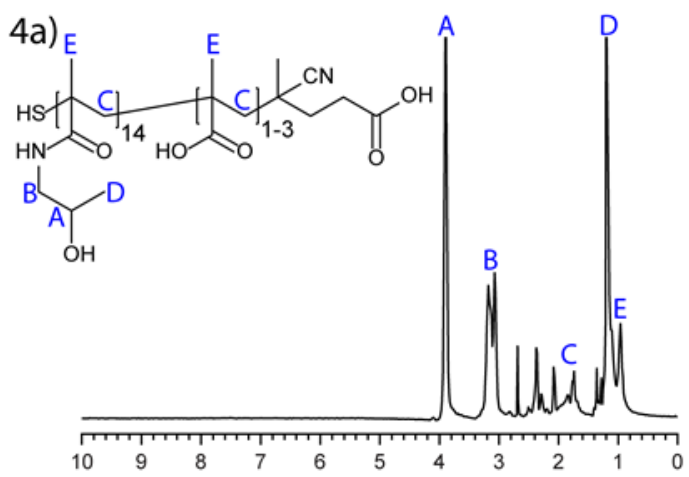

b)

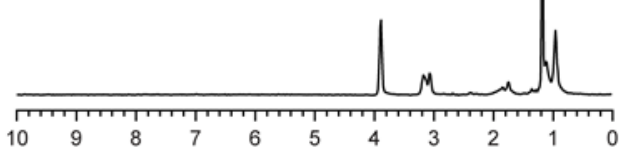

c)

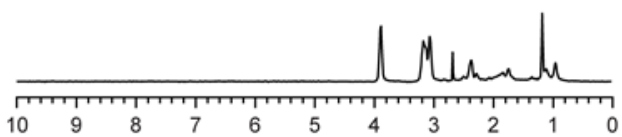

d)

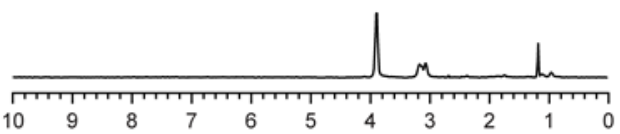

e)

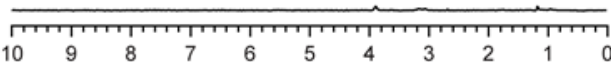

Figure S6. STD-NMR ( $600 \mathrm{MHz}, 3: 1 \mathrm{D}_{2} \mathrm{O} / \mathrm{DMSO}-d_{6}$ ) spectra of 3 ) $\mathbf{2 a}$ and 4 ) $\mathbf{2 b}$ polymers with BSA. a) are the reference (off-resonance) spectra measured with selective irradiation at $-40 \mathrm{ppm}$. Spectra $\mathrm{b}$ ) to e) are difference spectra obtained with selective irradiation at the frequencies: $0.65,2.60,4.30$ and 7.10 ppm, respectively. 
Table S3. Amplification factors (AsтD) of 2a with BSA irradiated at multiple frequencies.

\begin{tabular}{|c|c|c|c|c|}
\hline \multirow{2}{*}{ BSA irradiation frequencies } & \multicolumn{3}{|c|}{ Amplification factors (AstD) } \\
\cline { 2 - 5 } & $\mathbf{0 . 6 5} \mathbf{~ p p m}$ & $\mathbf{2 . 6 0} \mathbf{~ p p m}$ & $\mathbf{4 . 3 0} \mathbf{~ p p m}$ & $\mathbf{7 . 1 0} \mathbf{~ p p m}$ \\
\hline Polymer peaks & Methyls & Hydrophilic esters & Aromatics \\
\hline Benzene (7.40-7.98 ppm) & $8.4 \%$ & $7.5 \%$ & $4.5 \%$ & $13.5 \%$ \\
\hline HPMA & $16.9 \%$ & $14.3 \%$ & $7.0 \%$ & $0.7 \%$ \\
\hline
\end{tabular}

Table S4. Amplification factors (AsтD) of $\mathbf{2 b}$ with BSA irradiated at multiple frequencies.

\begin{tabular}{|c|c|c|c|c|}
\hline \multirow{2}{*}{ BSA irradiation frequencies } & \multicolumn{4}{|c|}{ Amplification factors (Asto) } \\
\cline { 2 - 5 } & $\mathbf{0 . 6 5} \mathbf{~ p p m}$ & $\mathbf{2 . 6 0} \mathbf{~ p p m}$ & $\mathbf{4 . 3 0} \mathbf{~ p p m}$ & $\mathbf{7 . 1 0} \mathbf{~ p p m}$ \\
\hline Polymer peaks & Methyls & Hydrophilic esters & Aromatics \\
\hline Benzene (7.40-7.98 ppm) & - & - & - & - \\
\hline $\begin{array}{c}\text { HPMA } \\
(\mathbf{1 . 1 8}, \mathbf{1 . 8 0}, \mathbf{3 . 1 5}, \mathbf{3 . 8 9} \mathbf{p p m})\end{array}$ & $18.4 \%$ & $15.6 \%$ & $7.5 \%$ & $0.8 \%$ \\
\hline
\end{tabular}




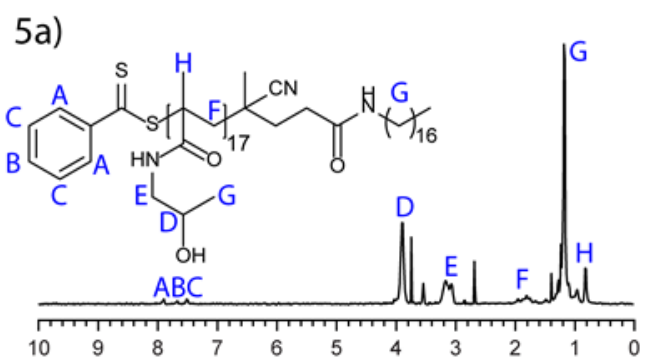

b)

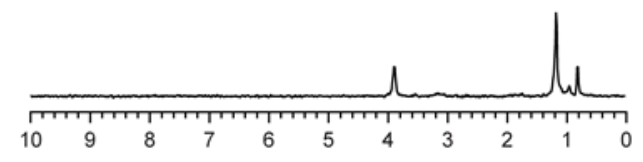

c)

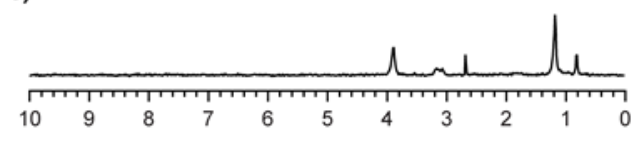

d)

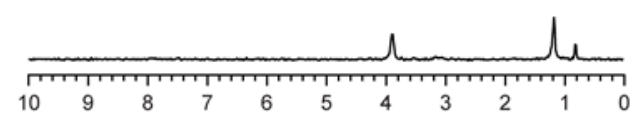

e)

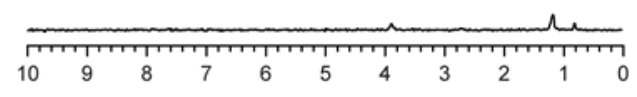

6a)

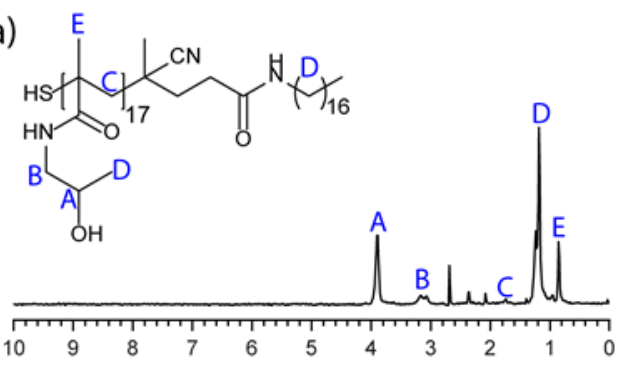

b)

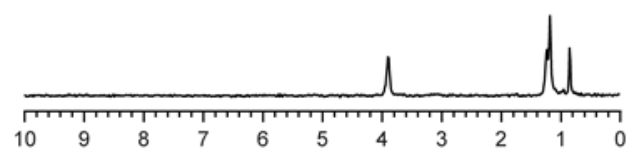

c)

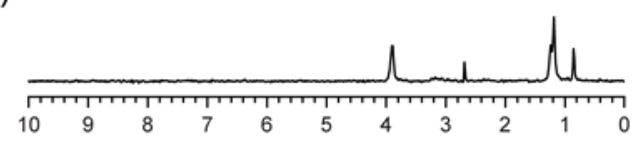

d)

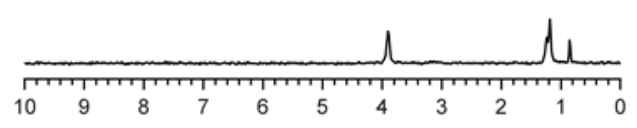

e)

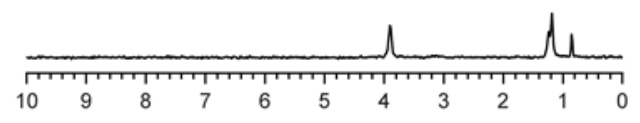

Figure S7. STD-NMR ( $600 \mathrm{MHz}, 3: 1 \mathrm{D}_{2} \mathrm{O} / \mathrm{DMSO}-d_{6}$ ) spectra of 5) 3a and 6) 3b polymers with BSA. a) are the reference (off-resonance) spectra measured with selective irradiation at $-40 \mathrm{ppm}$. Spectra $\mathrm{b}$ ) to e) are difference spectra obtained with selective irradiation at the frequencies: $0.65,2.60,4.30$ and 7.10 ppm, respectively.

Table S5. Amplification factors (AsтD) of 3a with BSA irradiated at multiple frequencies.

\begin{tabular}{|c|c|c|c|c|}
\hline \multirow{2}{*}{ BSA irradiation frequencies } & \multicolumn{4}{|c|}{ Amplification factors (Astd) } \\
\cline { 2 - 5 } & $\mathbf{0 . 6 5} \mathbf{~ p p m}$ & $\mathbf{2 . 6 0} \mathbf{~ p p m}$ & $\mathbf{4 . 3 0} \mathbf{~ p p m}$ & $\mathbf{7 . 1 0} \mathbf{~ p p m}$ \\
\hline Polymer peaks & Methyls & Hydrophilic esters & Aromatics \\
\hline Benzene (7.40-7.98 ppm) & $33.7 \%$ & $32.7 \%$ & $20.9 \%$ & $19.7 \%$ \\
\hline HPMA & $32.7 \%$ & $29.7 \%$ & $20.8 \%$ & $6.6 \%$ \\
\hline (1.18, 1.80, 3.15, 3.89 ppm) & $37.8 \%$ & $27.7 \%$ & $19.7 \%$ & $7.9 \%$ \\
\hline
\end{tabular}


Table S6. Amplification factors ( $A_{\text {SтD }}$ ) of $\mathbf{3 b}$ with BSA irradiated at multiple frequencies.

\begin{tabular}{|c|c|c|c|c|}
\hline \multirow{2}{*}{ BSA irradiation frequencies } & \multicolumn{4}{|c|}{ Amplification factors (AstD) } \\
\cline { 2 - 5 } & $\mathbf{0 . 6 5} \mathbf{~ p p m}$ & $\mathbf{2 . 6 0} \mathbf{~ p p m}$ & $\mathbf{4 . 3 0} \mathbf{~ p p m}$ & $\mathbf{7 . 1 0} \mathbf{~ p p m}$ \\
\hline Polymer peaks & Methyls & Hydrophilic esters & Aromatics \\
\hline Benzene (7.40-7.98 ppm) & \multicolumn{4}{|c|}{} \\
\hline $\begin{array}{c}\text { HPMA } \\
(\mathbf{1 . 1 8}, \mathbf{1 . 8 0}, \mathbf{3 . 1 5}, \mathbf{3 . 8 9} \mathbf{~ p p m )}\end{array}$ & $50.7 \%$ & $45.0 \%$ & $33.0 \%$ & $33.2 \%$ \\
\hline $\mathbf{S C}_{18}$ fatty acid tail (1.18 ppm) & $54.1 \%$ & $43.1 \%$ & $30.5 \%$ & $30.6 \%$ \\
\hline
\end{tabular}

7a)

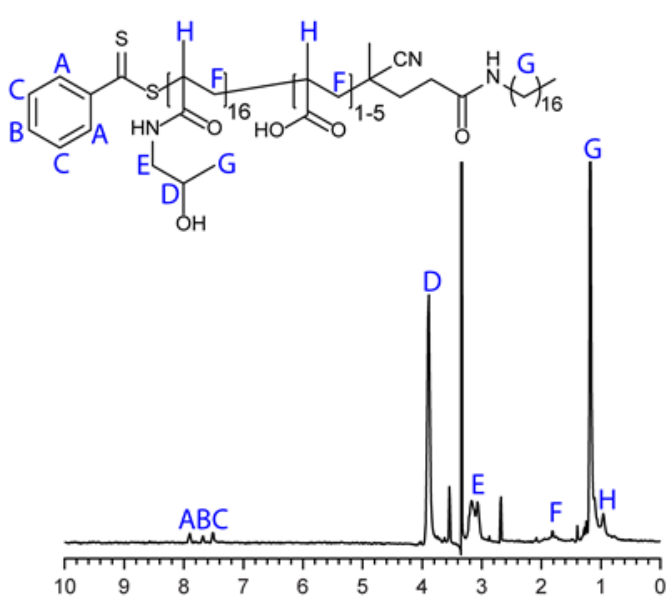

b)

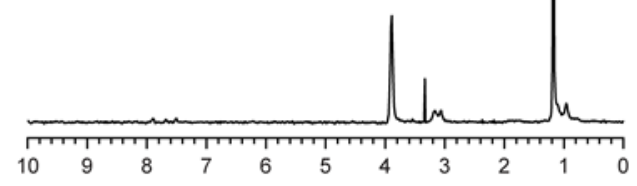

c)

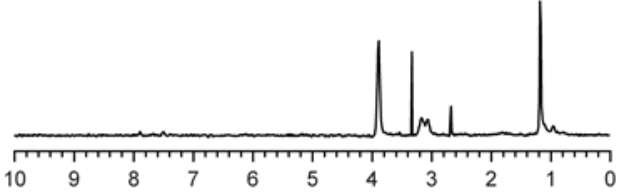

d)

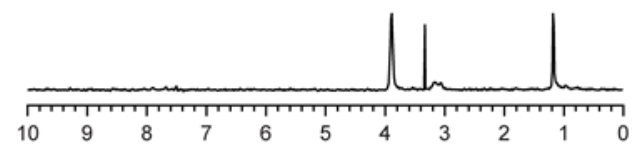

e)

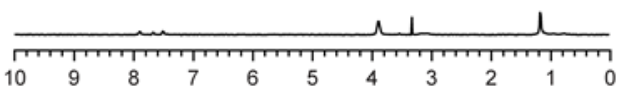

8a)
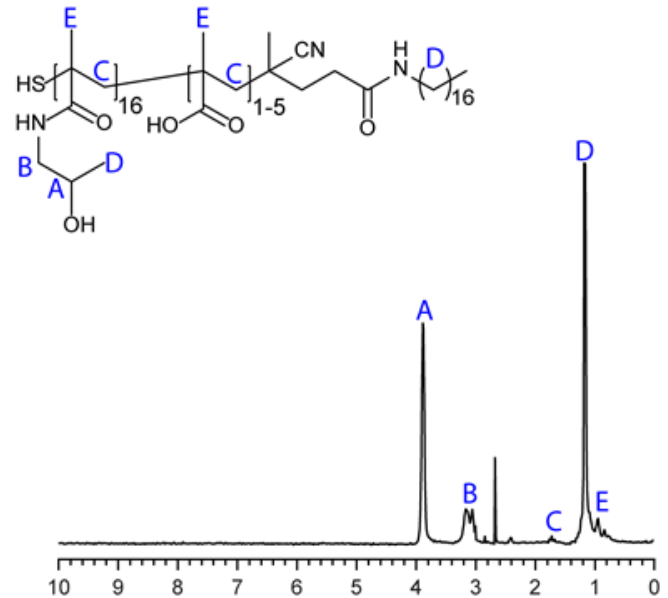

b)

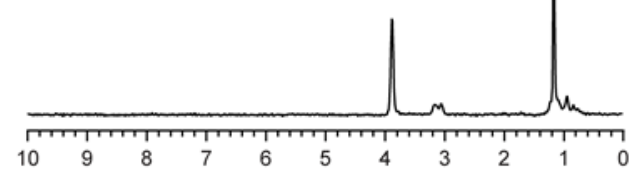

c)

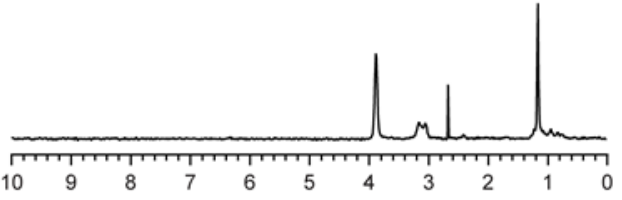

d)

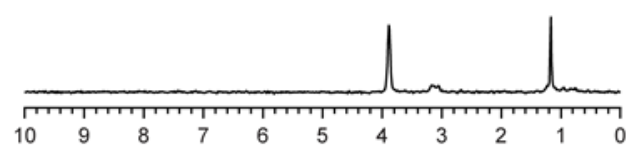

e)

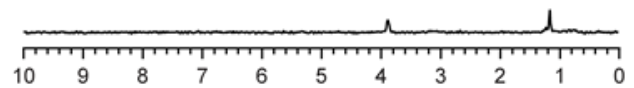

Figure S8. STD-NMR ( $\left.600 \mathrm{MHz}, 3: 1 \mathrm{D}_{2} \mathrm{O} / \mathrm{DMSO}-d_{6}\right)$ spectra of 7 ) $4 \mathbf{a}$ and 8 ) $4 \mathbf{b}$ polymers with BSA. a) are the reference (off-resonance) spectra measured with selective irradiation at $-40 \mathrm{ppm}$. Spectra $\mathrm{b}$ ) to e) are difference spectra obtained with selective irradiation at the frequencies: $0.65,2.60,4.30$ and 7.10 ppm, respectively. 
Table S7. Amplification factors (AsTD) of 4 a with BSA irradiated at multiple frequencies.

\begin{tabular}{|c|c|c|c|c|}
\hline \multirow{2}{*}{ BSA irradiation frequencies } & \multicolumn{4}{|c|}{ Amplification factors (AstD) } \\
\hline & \multirow{2}{*}{$\begin{array}{c}0.65 \text { ppm } \\
\text { Methyls }\end{array}$} & $2.60 \mathrm{ppm}$ & $4.30 \mathrm{ppm}$ & \multirow{2}{*}{$\begin{array}{l}7.10 \mathrm{ppm} \\
\text { Aromatics }\end{array}$} \\
\hline Polymer peaks & & \multicolumn{2}{|c|}{ Hydrophilic esters } & \\
\hline Benzene (7.40-7.98 ppm) & $40.5 \%$ & $37.8 \%$ & $28.3 \%$ & $35.4 \%$ \\
\hline $\begin{array}{c}\text { HPMA } \\
(1.18,1.80,3.15,3.89 \mathrm{ppm})\end{array}$ & $34.8 \%$ & $30.0 \%$ & $18.8 \%$ & $4.48 \%$ \\
\hline $\mathrm{SC}_{18}$ fatty acid tail (1.18 ppm) & $34.1 \%$ & $21.0 \%$ & $12.0 \%$ & $4.0 \%$ \\
\hline
\end{tabular}

Table S8. Amplification factors (AsTD) of $\mathbf{4 b}$ with BSA irradiated at multiple frequencies.

\begin{tabular}{|c|c|c|c|c|}
\hline \multirow{2}{*}{ BSA irradiation frequencies } & \multicolumn{4}{|c|}{ Amplification factors (AstD) } \\
\cline { 2 - 5 } & $\mathbf{0 . 6 5} \mathbf{~ p p m}$ & $\mathbf{2 . 6 0} \mathbf{~ p p m}$ & $\mathbf{4 . 3 0} \mathbf{~ p p m}$ & $\mathbf{7 . 1 0} \mathbf{~ p p m}$ \\
\hline Polymer peaks & Methyls & Hydrophilic esters & Aromatics \\
\hline Benzene (7.40-7.98 ppm) & & \multicolumn{2}{|c|}{-} & $4.9 \%$ \\
\hline $\begin{array}{c}\text { HPMA } \\
(\mathbf{1 . 1 8}, \mathbf{1 . 8 0}, \mathbf{3 . 1 5}, \mathbf{3 . 8 9} \mathbf{p p m})\end{array}$ & $37.6 \%$ & $30.9 \%$ & $19.2 \%$ & $4.6 \%$ \\
\hline $\mathbf{S C}_{18}$ fatty acid tail (1.18 ppm) & $37.1 \%$ & $22.6 \%$ & $12.7 \%$ & \\
\hline
\end{tabular}




\subsection{Sample preparation for $K_{D}$ measurements}

Briefly, polymer solutions $(0.1,0.2,0.5,1$ and $2 \mathrm{mM})$ were prepared in $\mathrm{PBS}_{2} \mathrm{O}(\mathrm{pH} 7.4,75$ $\mathrm{mM}$ ) in NMR tubes. Additional PBS $\mathrm{D}_{2} \mathrm{O}$ was added to the tube to adjust the total volume to $370 \mu \mathrm{L}$. DMSO- $d_{6}(150 \mu \mathrm{L})$ was then added to minimise any aggregation due to polymer amphiphilicity. The solution in the tube was thoroughly mixed before polymer spectra were generated. Finally, BSA $(0.02 \mathrm{mM})$ in $\mathrm{PBS} \mathrm{D}_{2} \mathrm{O}(80 \mu \mathrm{L})$ was added to the polymer solution and thoroughly mixed before performing the experiment. The molar ratio of polymer:BSA was kept consistent at 100:1 and the solvent system was $25 \%$ DMSO- $d_{6}$ in PBS $D_{2} \mathrm{O}$.
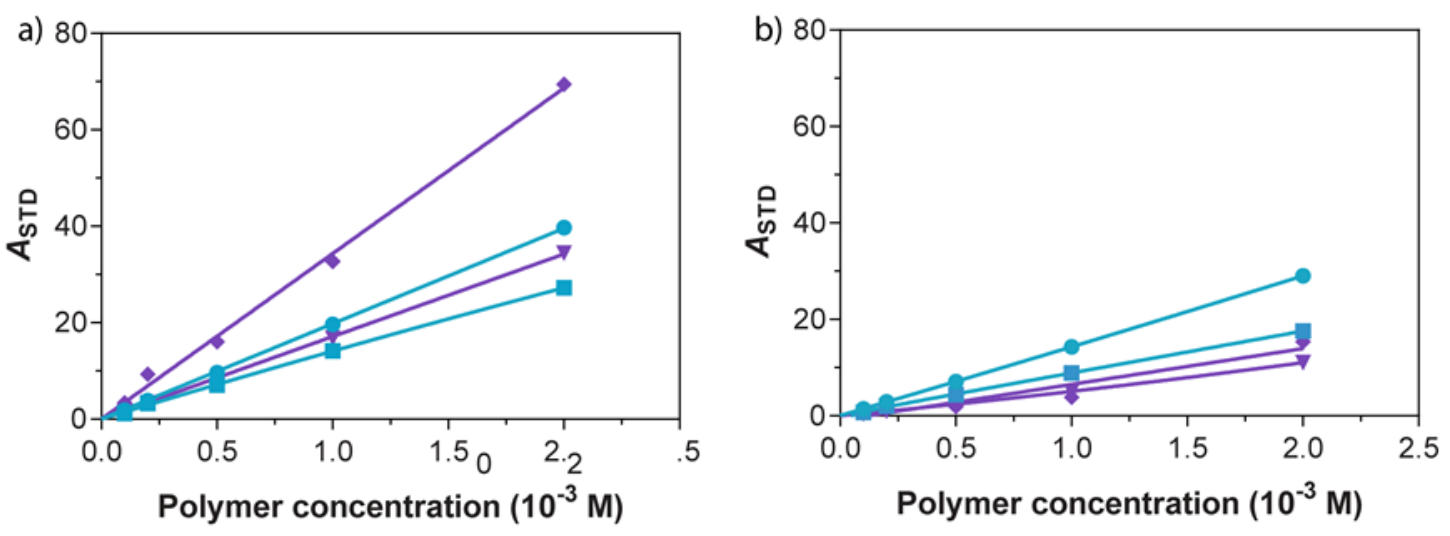

HPMA block $\mathrm{SC}_{18}$ fatty acid tail

Figure S9. Binding isotherms of AstD values of protons of polymer $4 \mathrm{~b}$ at different concentrations of the polymer in excess irradiated at the following frequencies a) $0.65 \mathrm{ppm}$ and b) $4.30 \mathrm{ppm}$. 


\section{Fluorescence spectroscopy}

\subsection{Sample preparation}

BSA solutions $(50 \mu \mathrm{M})$ were prepared in PBS $(\mathrm{pH} \mathrm{7.4,} 75 \mathrm{mM})$. Polymer solutions, prepared in PBS ( $\mathrm{pH} 7.4,75 \mathrm{mM}$ ) were added in $0,0.25,0.5,0.75,1,2,3$ and 4 molar equivalence to BSA. Samples were excited at $290 \mathrm{~nm}$ and emission was measurement from $300-500 \mathrm{~nm}$. BSA-polymer solutions were incubated at $25^{\circ} \mathrm{C}, 30^{\circ} \mathrm{C}$ and $35^{\circ} \mathrm{C}$ for 5 min prior to each measurement.
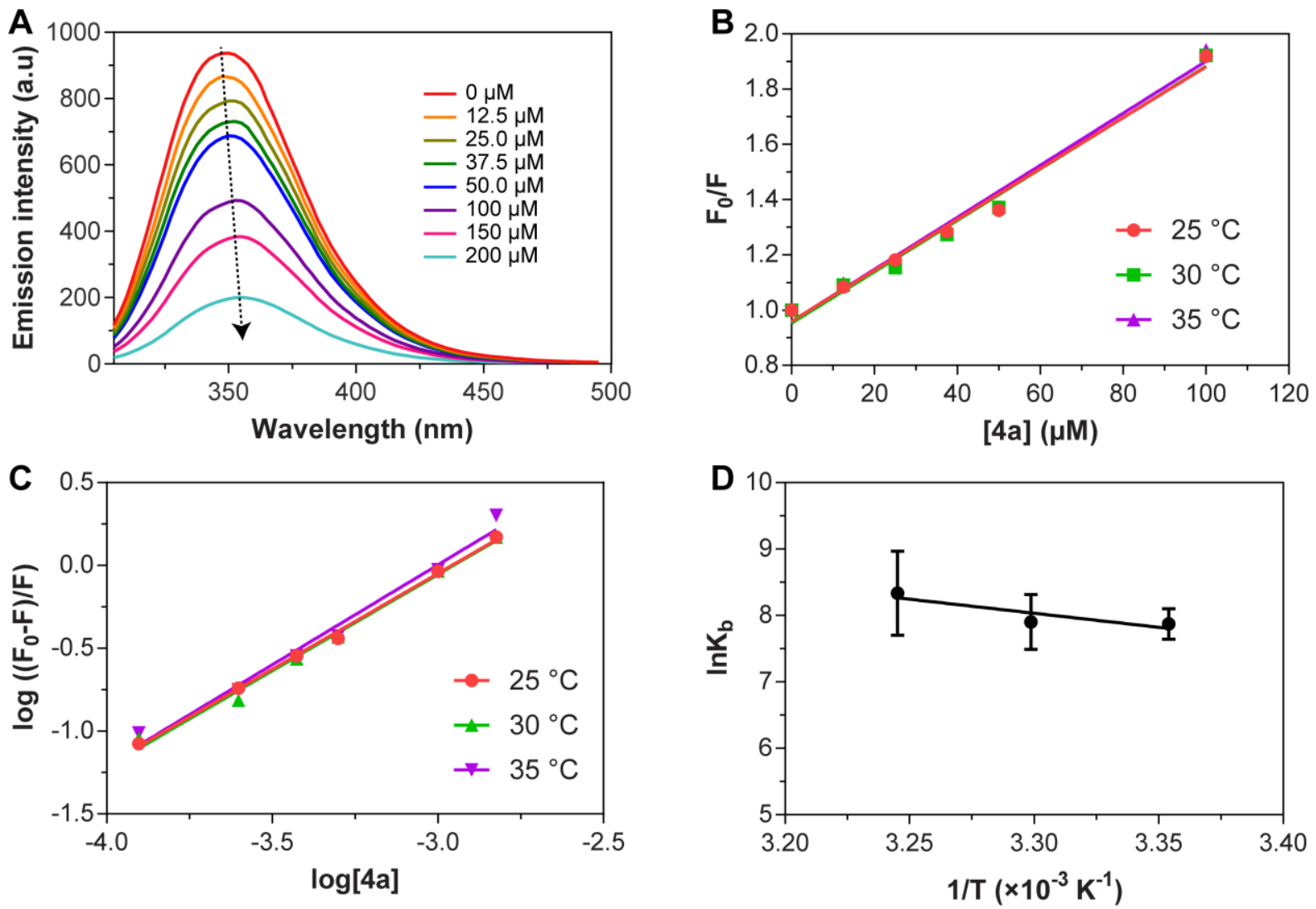

Figure S10. Fluorescence spectroscopy plots of BSA-4a samples. A) BSA fluorescence quenching plot where increased polymer concentrations induce quenching. B) Stern-Volmer plots generated from fluorescence quenching at $25^{\circ} \mathrm{C}, 30^{\circ} \mathrm{C}$ and $35^{\circ} \mathrm{C}$. C) $\log \left(F_{0}-F\right) / F$ versus $\log [\mathrm{Q}]$ plots generated from fluorescence quenching at $25^{\circ} \mathrm{C}, 30^{\circ} \mathrm{C}$ and $35^{\circ} \mathrm{C}$. D) van't Hoff plot for BSA-4a binding. 

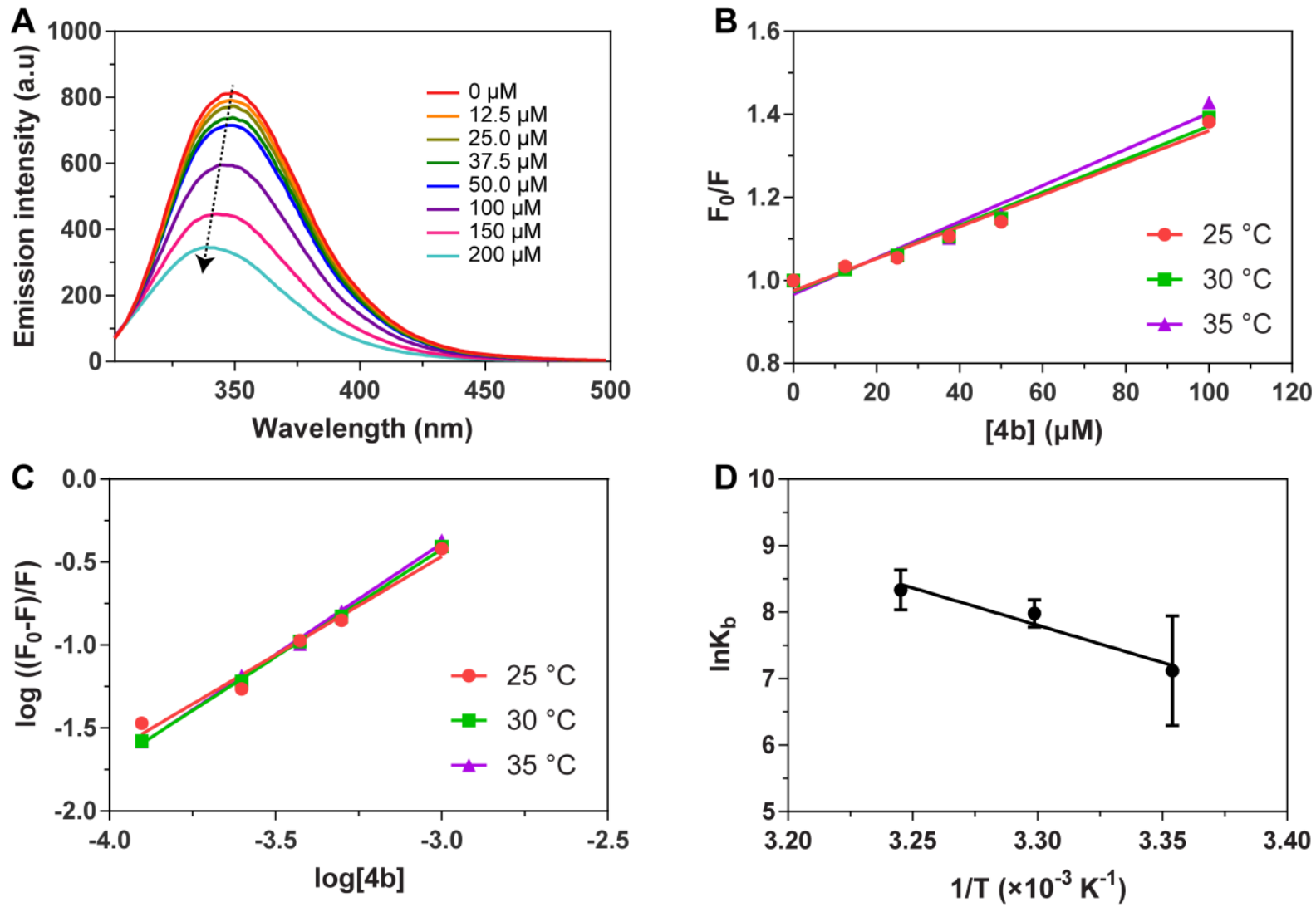

Figure S11. Fluorescence spectroscopy plots of BSA-4b samples. A) BSA fluorescence quenching plot where increased polymer concentrations induce quenching. B) Stern-Volmer plots generated from fluorescence quenching at $25^{\circ} \mathrm{C}, 30^{\circ} \mathrm{C}$ and $35^{\circ} \mathrm{C}$. C) $\log \left(F_{0}-F\right) / F$ versus $\log [\mathrm{Q}]$ plots generated from fluorescence quenching at $25^{\circ} \mathrm{C}, 30^{\circ} \mathrm{C}$ and $35^{\circ} \mathrm{C}$. D) van't Hoff plot for BSA-4b binding. 
5.2 Elucidation of the thermodynamic parameters

The thermodynamic parameters of the binding between $\mathbf{4 a}$ and $\mathbf{4 b}$ was determined from the van't Hoff plot illustrated in Figures S9 D) and S10 D). First by following Equation 1, $\Delta G$ was determined.

$$
\Delta G=-R T \ln K_{b}
$$

Equation 1 where:

$\mathrm{R}$ is the gas constant $\left(8.3145 \mathrm{~J} \cdot \mathrm{K}^{-1} \cdot \mathrm{mol}^{-1}\right)$

$\mathrm{T}$ is the temperature in Kelvins

$K_{\mathrm{b}}$ determined from the $\log \left(F_{0}-F\right) / F$ versus $\log [\mathrm{Q}]$ plots

$\Delta H$ was obtained from Equation 2.

$$
\ln \left(\frac{K_{2}}{K_{1}}\right)=-\frac{\Delta H}{R}\left(\frac{1}{T_{2}}-\frac{1}{T_{1}}\right)
$$

Equation 2 where:

$K_{2}$ is the $K_{b}$ at $303.15 \mathrm{~K}$

$K_{1}$ is the $K_{b}$ at $293.15 \mathrm{~K}$

$R$ is the gas constant $\left(8.3145 \mathrm{~J} \cdot \mathrm{K}^{-1} \cdot \mathrm{mol}^{-1}\right)$

$T_{2}$ is $303.15 \mathrm{~K}$ and $T_{1}$ is $293.15 \mathrm{~K}$

Finally, $\Delta S$ was obtained from Equation 3.

$$
\Delta G=\Delta H-T \Delta S
$$

Equation 3 where:

$\Delta G$ was determined from Equation 1

$\Delta H$ was determined from Equation 2

$\mathrm{T}$ is the temperature in Kelvins

\begin{tabular}{|c|c|c|c|c|c|c|c|c|c|}
\hline Polymer & $T(\mathrm{~K})$ & 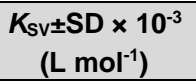 & $\begin{array}{c}k_{\mathrm{q}} \times 10^{5} \\
\left(\mathrm{~L} \mathrm{~mol}^{-1} \mathrm{~s}^{-1}\right)\end{array}$ & $\mathbf{R}^{2}$ & 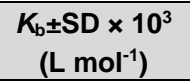 & $n$ & $\begin{array}{c}\Delta H \\
(\mathrm{~kJ} / \mathrm{mol})\end{array}$ & $\begin{array}{c}\Delta S \\
(\mathrm{~J} / \mathrm{K} / \mathrm{mol})\end{array}$ & $\begin{array}{c}\Delta G \\
(\mathrm{~kJ} / \mathrm{mol})\end{array}$ \\
\hline \multirow{3}{*}{$4 a$} & 298 & $9.214 \pm 0.53$ & 9.214 & 0.987 & $2.624 \pm 0.001$ & 1.16 & \multirow{3}{*}{15.7} & 128.0 & -21.9 \\
\hline & 303 & $9.303 \pm 0.58$ & 9.303 & 0.985 & $2.704 \pm 0.002$ & 1.16 & & 125.8 & -22.4 \\
\hline & 308 & $9.418 \pm 0.57$ & 9.418 & 0.986 & $4.169 \pm 0.001$ & 1.21 & & 123.7 & -23.1 \\
\hline \multirow{3}{*}{$4 b$} & 298 & $3.854 \pm 0.19$ & 3.854 & 0.975 & $1.233 \pm 0.002$ & 1.19 & \multirow{3}{*}{90.0} & 366.2 & -17.3 \\
\hline & 303 & $3.993 \pm 0.18$ & 3.993 & 0.979 & $2.931 \pm 0.001$ & 1.30 & & 368.2 & -19.8 \\
\hline & 308 & $4.365 \pm 0.16$ & 4.365 & 0.973 & $4.169 \pm 0.001$ & 1.34 & & 366.2 & -21.0 \\
\hline
\end{tabular}

Table S9. Summary of Stern Volmer, binding constant $\left(K_{b}\right)$, binding sites $(n)$ and thermodynamic parameters of the interaction of polymers $\mathbf{4 a}$ and $\mathbf{4 b}$ with BSA. 


\section{Circular dichroism}

\subsection{Sample preparation}

BSA solutions $(5 \mu \mathrm{M})$ were prepared in PBS $(\mathrm{pH} 7.4,75 \mathrm{mM})$. Polymer solutions, prepared in PBS (pH 7.4, $75 \mathrm{mM}$ ) were added in $0,0.25,0.5,0.75,1,2,3$ and 4 molar equivalence to BSA. Samples were measured from 200-250 nm. BSA-polymer solutions were incubated at $25^{\circ} \mathrm{C}$ for 5 min prior to each measurement.
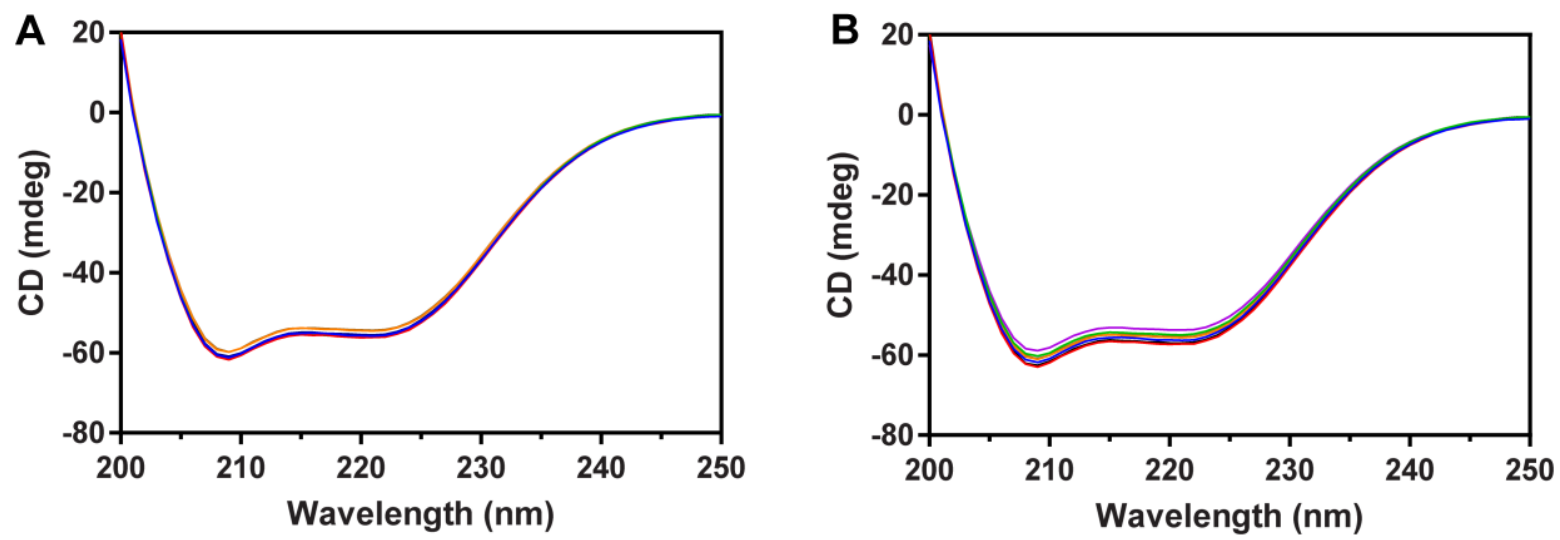

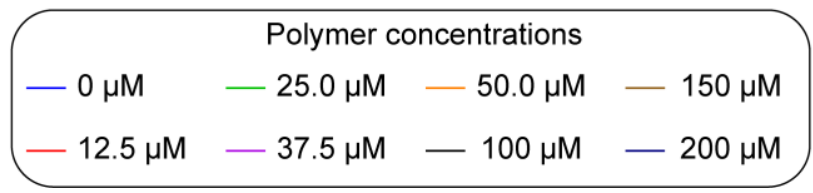

Figure S12. Circular dichroism spectra of A) BSA-4a and B) BSA-4b samples measured at $25^{\circ} \mathrm{C}$ with increasing concentrations of the polymer $(0-20 \mu \mathrm{M})$.

\section{References}

(1) Mitsukami, Y.; Donovan, M. S.; Lowe, A. B.; McCormick, C. L. Water-Soluble Polymers. 81. Direct Synthesis of Hydrophilic Styrenic-Based Homopolymers and Block Copolymers in Aqueous Solution via RAFT. Macromolecules 2001, 34, 2248-2256.

(2) Fairbanks, B. D.; Thissen, H.; Maurdev, G.; Pasic, P.; White, J. F.; Meagher, L. Inhibition of Protein and Cell Attachment on Materials Generated from N-(2-Hydroxypropyl) Acrylamide. Biomacromolecules 2014, 15, 3259-3266.

(3) Scales, C. W.; Convertine, A. J.; McCormick, C. L. Fluorescent Labelling of RAFT-Generated Poly(N-Isopropylacrylamide) via a Facile Maleimide-Thiol Coupling Reaction.

Biomacromolecules 2006, 7, 1389-1392. 